\title{
Peer Conformity Through Money Attitudes Toward Adolescence's Consumptive Behavior
}

\author{
Dyanti Mahrunnisya ${ }^{*}$; Mintasih Indriayu; Dewi Kusuma Wardani \\ Sebelas Maret University, Surakarta, Indonesia \\ Email: dyantianis@gmail.com
}

http://dx.doi.org/10.18415/ijmmu.v5i4.163

\begin{abstract}
This study aims to determine the effect of peer conformity through money attitudes toward adolescence's consumptive behavior. The method used is descriptive verification method with ex post facto and survey approach. Data collecting technique was done by using questionnaire. Sampling technique in this study was proportional stratified random sampling, the number of samples were 165 adolescents. Hypothesis testing in this study was conducted by using linear regression test with path analysis. The results show the significance of peer conformity influence on consumptive behavior was $32.4 \%$. The value of the influence of peer conformity to consumer behavior is indirectly obtained by 11 , $22 \%$. The findings indicated all hypotheses were accepted, that peer conformity shows a significant effect on consumptive behavior. Adolescent who have high conformity will tend to behave consumptively.
\end{abstract}

Keywords: Conformity; Consumptive Behavior; Money Attitude;

\section{Introduction}

Consumptive behavior is a phenomenon occurs in urban society. This phenomenon is interesting to be studied also consider that consumptive behavior hit many adolescent life in big city. Consumptive behavior is the emergence of the desire to buy less necessary goods to fulfill personal satisfaction. Nowadays the need does not relate to the value of the utility of an object, it is now associated with symbolic elements of a particular class, social status, as stated by Goldsmith, Flynn and Clark (2012) show to a consumer's social status, one of the ways is by purchasing and showing the product. There are many reasons for more consumptive behavior by adolescents, because they are in the process of personality finding and very sensitive to outside influences, both positive and negative, as stated by Scully and Moital (2016) a social influence give impact on thoughts, feelings, and actions individuals, some activities done by others, then adolescence a period where full of emotional fluctuation and unbalanced emotion, adolescents easily exposed to the environment. In addition, understanding a person's attitude toward money is important because it can determine the behavior of an individual.

Money can provide a psychological experience for the owner. Some people who are there are sacred, feared, respected and adored (Furnham \& Argyle., 1998). Money Attitude shows money has many meanings according to the level of understanding and personality of a person who becomes an important 
part of a person's life, source of respect, quality of life, freedom and even evil (Duravasula \& Lysonsnki., 2007). According to Dunn (2005) stated that one's mental health can be accessed by money and social behavior of the individual can be seen from how a person has perspective toward money. Dontosov, Zinchenko, Zotova (2013) stated the same thing that an individual will experience changes in perspective and behavior due to money.

Adolescence is the age at which someone begins to want to be conveyed, adolescents do various ways to try to be part of their surroundings. This fact indicates that the social environment supports a competitive atmosphere to show that they are up to date to the recent fashion which is more affecting adolescents. This is supported by the opinions of McGhie, Lewis, and Hyde (2012) who stated that conformity is a tendency to follow individual behaviors, actions, values, and ideas to look alike and avoid conflict between friends. This problem can also happen to most adolescents in Bandar Lampung City, this is supported by the condition of Bandar Lampung City which alternately adjacent to the capital city of Jakarta which has a tendency to always follow the trend in big cities.

The geographical location leads Bandar Lampung to seize the opportunity to become one of the growth centers that play a role in the regional economic system IMS-GT or part of Indonesia's big economic activity. Bandar Lampung opportunity to fill the economic functions are selective, and competitive, in the central growth system existing. Bandar Lampung has a great opportunity on the economic sector to establish into a center of trade and services on the scale of Southern Sumatra. In line with the phenomenon makes Bandar Lampung city which is the capital of Lampung Province and the gateway between Java Island and Sumatera Island that can quickly influence the society in adolescence in various things, ranging from lifestyle to the order of norms of life.

\section{Literature Study 2.1. Peer Conformity (X)}

Peers are people with similar maturity or age levels. Santrock (2003) stated that peers are people who gather with the same age and maturity. One of the most important functions of peer groups is to provide a source of information and comparisons about the world of society. Through peer groups children receive feedback from their peers about their abilities. Peer group is an important socialization institution in addition to family, because peer group also teaches the way of life in society. Scully and Moital (2016) added "individual is influenced by others, but they also try to influence others ". Supporting the opinions above Cialdini and Goldstein (2004) reveals that conformity refers to the act of changing one's behavior to fit the response of others, based on the desire to form an accurate interpretation of reality and behave correctly, and based on the goal to obtain social recognition from others.

The effect of conformity on peer groups in adolescence cannot be ignored. A peer group can influence one's own attitude and image. Counseling is formed and influenced by the social environment around adolescents. One form of social influence is in the form of social norms and values that become mutual agreement to regulate adolescents' behavior as to create a uniform behavior in the group. Based on the above explanation it is explained that peer conformity is an attitude that is followed by a person to adjust to peers in the group with the reasons to be accepted and recognized by the group. Here is an indicator of peer conformity that put forward by Sears (1985): 


\section{a. Solidarity}

Conformity is influenced by the close relationship between individuals and groups. This solidarity is the power that causes others to be attracted to a group and makes everyone want to be a member. The greater one member's passion for the other, and the greater the hope of benefiting from group membership and the greater their loyalty, the more solid the group is.

\section{b. Agreement}

Agreements in this regard are expected of individuals within the group to adapt and comply with the rules that apply within the group.

\section{c. Obedience}

Peer conformity demands pressure in a benchmark group in adolescents that make they are willing to act even when they does not want it. Individuals must be willing to abide the group and able to meet the demands of others in their group and are expected to cooperate in such groups and maintain mutual trust towards group members.

\subsection{Money Attitude (Z)}

Money is very intimately in the interaction of society and has different symbolic parameters for each person. The theoretical analysis of modern research shows that money has acquired not only the essence of financial but also psychological value. It has changed to one of the basic dimensions of human relations and behavior. Money is a very useful item in modern life. It can be said that everyone needs money for the survival of his life. There are at least three main functions of a money, namely as a store of value unit, as a Unit of Account and as a Medium of Exchange. According to the results of research conducted by Foster (2001) attitudes toward money are often interpreted as a motivation for having the money. This is supported by Teng, Chen, Poon (2016) reveals that money has existence everywhere especially in modern commercial society, money can shape the way people perceive themselves and influence how they behavior.

Monteros, Penaloza, Pinto, Coria, Calderon (2015) argue that the value of money depends on the individual itself, but in money there are social values and society argues that money is a source of strength and happiness. Dontosov, Zinchenko, Zotova (2013) added that money is a means of existence to get education and educate children, money is a source of energy, but at the same time it can lead to conflict, war and contention. Money can often provide security, but it can also be a threat. According to Bonsu (2008) the individual's attitude towards money is influenced by culture and individual differences including gender and personal values of money attitude are also observed to have strong relationships with personality traits, the importance of money attitude ranges from demographic factors such as family, life cycle, age, educational level and social status.

Based on the above understanding it can be synthesized that the definition of attitudes toward money is a manifestation of behavior as a result of an evaluation of the benefits of ownership, usefulness and symbolic meaning of money that affect the buying behavior of individu. These are the dimension of money attitude by Yamauchi and Templer (1986) and Money Ethic Scale (MES) by Tang (1992): 
a. Power-Prestige: it is a dimension that indicates that an individual believes that money is a symbol of power.

b. Good: Components in this factor represent good behavior toward money, for example money is important, money is valuable.

c. Evil: The components in this factor express negative behavior toward money, for example money is the source of evil, money is useless.

d. Budget: This factor is related to the behavior of how someone budget his money.

e. Achievement: money symbolizes the achievement of a person and the symbol of success.

\subsection{Consumptive Behavior (Y)}

Consumptive behavior is a buying behavior and use of goods that are not based on rational considerations and have a tendency to consume something indefinitely where the individual is more concerned with the factor of desire than the needs and it is characterized by the existence of luxury and extravagant life, the use of all the most luxurious things that give satisfaction and physical comfort. Schiffman and Kanuk (2000) declare consumptive behavior is a behavior of consumers in searching, buying, using, evaluating and determining product services. Consumption behavioral terms are defined as behaviors that indicate by people in planning, buying and which are problems is when the tendency which is actually natural but in this community it is done in extravagant way. The indicators of consumptive behavior are as follows:

a. Buying products is not based on benefits or utility

Consumers tend to behave characterized by the existence of luxury life so that they tend to use everything that is considered the most luxurious.

b. Buying a product just keeps the status symbol

Consumers have a high buying ability in dressing, grooming, hairstyle, so that can support exclusive properties with expensive items and give the impression comes from a higher social class. Purchasing a product can provide status symbols to look fancier in other people perspective.

c. Family Lifestyle

One other very important function in relation to family functions and consumer behavior is lifestyle functions appropriate for members of his family. Lifestyle function describes family activities that should be done to train the child as a good consumer.

\section{Correlations and Hypothesis}

\subsection{Peer Conformity and Consumptive Behavior}

Consumptive behavior is very varied, but in essence the consumptive sense is to buy goods without rational considerations or not on the needs. One factor that affects consumptive behavior is a group. In this case, adolescents who have social relationships with peer group can give influence in decision making in conducting consumption behavior. If adolescents more conform to social group in this group of peers, adolescent will be progressively consumptive.

H1: There is an Influence of Peer Conformity against Consumpve Behavior of Adolescents. 


\subsection{Peer Conformity, Money Attitude and Consumptive Behavior}

Attitudes toward money and peer conformity affect the behavior of adolescents in consumption. Reference groups as a group that is considered as a frame of reference for individuals in making purchasing decisions or juvenile consumption. This reference group is very strong influence the lives of individuals. At this stage adolescents are required to start practicing achieving economic self-sufficiency. In reality, adolescents do not do things that are related to economic independence, they tend to do other things related to excessive purchasing or consumptive behavior. It becomes a problem when the real trend is fair to this adolescent is done excessively, because adolescents do not see the value of money from its function but by way of another view of the value of money, money can give happiness, money can bring friends, and with their money get recognition from the surrounding environment.

H2: There Is Influence Peer Conformity Through Money Attitude Toward Consumptive Behavior.

\section{Methodology}

The method used in this research is descriptive verification method with ex post facto and survey approach. Sampling method in this research is by using Promotional Stratified Random Sampling. Samples in this study were 165 adolescents in Bandar Lampung City. The data in this study were obtained by using Questionnaire, with a total of 40 items. Hypothesis testing in this study was conducted by using linear regression test with path analysis.

\section{Results and Discussions}

\subsection{Influence of Peer Conformity Toward Consumptive Behavior}

Table 1 Influence of peer conformity toward consumptive behavior

\begin{tabular}{|c|c|c|c|c|c|}
\hline \multirow[t]{2}{*}{ Model } & \multicolumn{2}{|c|}{ Unstandardized Coefficients } & \multirow{2}{*}{$\begin{array}{l}\text { Standardized } \\
\text { Coefficients } \\
\text { Beta }\end{array}$} & \multirow[b]{2}{*}{$\mathrm{T}$} & \multirow[b]{2}{*}{ Sig } \\
\hline & B & Std. Error & & & \\
\hline (Constant) & 19.950 & 1.660 & & 12.020 & .000 \\
\hline Peer conformity (X) & .311 & .075 & .324 & 4.120 & .000 \\
\hline
\end{tabular}

Dependent variable: Consumptive behavior (Y)

Based on these calculations, it shows that $\mathrm{t}_{\text {calc }}$ is 4,120 and significance level (sig.) is 0.000 . While $\mathrm{t}_{\text {table }}$ with $\mathrm{dk}=165-2$ with $\alpha=0,05$ it was obtained 1,97. Thus, $\mathrm{t}_{\text {calc }}>\mathrm{t}_{\text {table }}$ or $4.120>1.97$ and (sig.) as $0.000<0.05$ consequently Ho is rejected and $\mathrm{H} 1$ is accepted. This means that peer conformity affects teen consumptive behavior. The results of the calculation of path coefficients $\rho Y X$ of 0.324 means the significance of peer conformity influence on consumptive behavior was 0.324 or $32.4 \%$. Adolescent who have high conformity to a group, will have a high consumptive behavior. This proves consumptive behavior undertaken by adolescents actually cannot be separated from the influence of the social environment in interacting with his group this is because within a group has solidarity, obedience, and agreement. 
Adolescents who have high conformity will have a high sense of solidarity that causes adolescent spend much time to shop with friends, and have the purpose of forming a group to be easily recognized in the environment. Adolescent who have high conformity in group adherence will also purchase a product suggested by their group's friends even if the product is not needed, is more likely to comply with the rules of the group, and avoids disputes within the group by following the group's wishes such as shopping together. Students with high conformity will have a high degree of agreement in their group, this is characterized by students always buying products purchased by a group of friends and having full confidence in the group for their best performance. This study supports the opinion of Papalia \& Olds (2002), if friends in teen groups tend to have consumptive behavior, then because of the interaction, the adolescent is also likely to follow the consumptive behavior of the group.

\subsection{Peer Conformity Influence Through Money Attitude Toward Consumptive Behavior}

Based on Figure 1, the path diagram, it can be calculated the influence of peer conformity variables on consumer behavior through money attitude of:

$$
\begin{aligned}
\mathbf{X} \longrightarrow \mathbf{Z} \longrightarrow \mathbf{Y} \\
\rho Z \mathrm{X} \times \mathrm{PYZ}=(0,501 \times 0,224)=0.112224=11,22 \%
\end{aligned}
$$

The value of the influence of peer conformity to consumer behavior is indirectly obtained by 0.073 have positive mark which means that the hypothesis stated that there is influence of peer conformity to consumptive behavior through money attitude can be accepted. This explains that the peer conformity through money attitude has an effect on consumptive behavior with the influence level of 7.3\%. This means that consumptive behavior will arise when a person has an excessive attitude toward money along with high conformity.

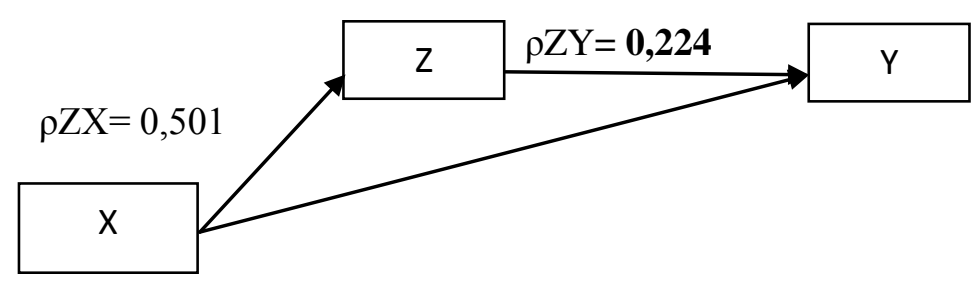

Fig 1. The effect of $\mathrm{X}$ toward $\mathrm{Y}$ through $\mathrm{Z}$

In the daily life of individuals or groups of individuals cannot be separated from the relationship with each other in an attempt to adjust to the environment, so the habits between individuals and skills sometimes there is the same because there are aspects of solidarity, agreement and obedience in a group. It implies that money gives strength, money gives goodness, money rewards, and money can also be a symbol of evil. What is a tantalizing topic, almost everything needs money. Money is not only meets primary, secondary, tertiary, social and spiritual needs, but money can also elevate the ego.

In other words, the influence of peers affects consumptive behavior through one's attitude toward money, someone who considers money as a force in his life will use money to buy a luxury that can be 
shown to others so that a person can be recognized in his group. This study supports Cialdini and Goldstein (2004) who revealed that conformity refers to the act of changing one's behavior to fit the response of others, based on the desire to form an accurate interpretation of reality and behave correctly, and based on the goal of obtaining social recognition from others.

\section{Conclusions}

Based on the results of analysis and discussion in this study, it can be concluded that there is significant influence of peer conformity through money attitude toward consumptive behavior. The higher the level of peer conformity and money attitude of an adolescent, the higher the consumptive behavior would be. In this study the level of influence of peer conformity to consumptive behavior is $32.4 \%$, thus the hypothesis of "there is influence of peer conformity to consumptive behavior in adolescents" is acceptable. The significance of influence of peer conformity through money attitude toward consumptive behavior was 11, $22 \%$. This can accept the hypothesis of "there is influence peer conformity through money attitude toward consumptive behavior in adolescents". Basically consumptive behavior can be avoided by knowing the factors that affect a person to be consumptive, such as reducing the level of conformity to friends and be reasonable toward money.

\section{References}

Bonsu, S. K. (2008). Ghanqian Attitudes Toward Money in Consumer Culture. Journal of Consumer Studies. 32: 171-178.

Cialdini, R. Goldstein, N. J. (2004). Compliance and Conformity. Social Influence. 55: 591-621.

Dontsov, A. I., Zinchenko, Y. P., Zotova, O. Y. (2013). Nations of Secrurity as a Component of Students Attitudes Towards Money. Social and Behavioral Sciences. 86: 93-103.

Dunn, L. F., \& Mirzaie, I. A. (2005). Determinants of Consumer Debt Stress: Differences by Debt Type and Gender: Working paper.

Duravasula, S., \& Lysonski, S. (2007). Money attitudes, materialism, and achievement vanity: An investigation of Young Chinese Consumerse perceptions. International Marketing Conference on Marketing \& Society. 6(1): 497-499.

Furnham, A., \& Argyle, M. (1998). The psychology of money. London and New York: Routledge.

Golsmith, R. E., Flynn, L. R., Clark, R. A. (2012). Matrealistic, Brand Engaged and Status Consuming Consumers and Clothing Behaviors. Journl of Fashion Marketing and Management. 6(1): 102-119.

McGhie, A. Lewis, I., Hyde, M. K. (2012). The Influence of Confirmity and Group Identity On Drink Walking Intentions. Accident Analysis and Prevention.(4): 693-645.

Monteiru, D. L. C., PPeneloza, V., Pinto, F. R., Coriaa, M. C. D., Caldeon, L. M. O. (2015). Attitudes Towards Money and Motivational Orientation to Work in Brazilian Young Workers. Contaduria Y Administration, 60: 11-30.

Papalia, D. E., Old, S. W., Feldman, R. D. (2002). Perkembangan Manusia. Jakarta: Salemba Humanika.

Santrock. (2003). Adolescence. Jakarta: Erlangga. 
Sciffman. L. G., Kanuk, L. L. (2000). Consumer Behavior. Fifth Edition, Prentice Hall Inc: New Jersey.

Scully, K., \& Moital, M. (2016). Peer Influence Strategis in Collectively Consumed Products. Young Consumer, 17(1): 46-63.

Tang, T. (1992). The Meaning of Money Revisited. Journal of Organization Behavior, 13:197-202.

Teng. F., Chen.Z., Poon. K. T., Zhang. D., Jiang. (2016). Money and Relationship: When and Why Thinking About Money Leads People to Approach Others. Organizational Behavior and Human Decision Processes. 137: 58-70.

Yamuchi. K. T \& Templer D. I. (1982). The Development of a money attitude scale. Journal of Personality Assessment, 46: 522-528.

\section{Copyrights}

Copyright for this article is retained by the author(s), with first publication rights granted to the journal.

This is an open-access article distributed under the terms and conditions of the Creative Commons Attribution license (http://creativecommons.org/licenses/by/4.0/). 